The Historical Fournal, 54, 2 (2011), pp. 509-528 (C) Cambridge University Press 2011. The online version of this article is published within an Open Access environment subject to the conditions of the Creative Commons Attribution-NonCommercial-ShareAlike licence < http://creativecommons.org/licenses/by-nc-sa/2.5/ > . The written permission of Cambridge University Press must be obtained for commercial re-use.

doi:10.1017/Soor $8246 \mathrm{X}_{\text {Ioooo } 646}$

\title{
MAKING THE PATIENT-CONSUMER IN MARGARET THATCHER'S BRITAIN
}

\author{
ALEX MOLD \\ London School of Hygiene and Tropical Medicine
}

\begin{abstract}
A B S T R ACT. This article examines the role played by patient organizations in the making of the patient as consumer during Margaret Thatcher's term as prime minster. It details a crucial moment in the reconstitution of the relationship between state and citizen, as universal entitlements to welfare gave way to individualistic rights to, and choice of, services. Though patients had been regarded as consumers prior to this period, it was during the Ig8os that the patient-consumer moved from the margins to centre-stage. By examining the activities of patient groups around three key themes - the provision of information, the development of patients' rights, and the notion of patient choice - this article showes that ideas about what it meant to be a patient-consumer came initially from patient groups. Through their work in these areas, patient groups built up a kind of patient consumerism that was concerned with the needs of the wider population, as well as representing demands made by individual patient-consumers. By the end of the Igoos, however, the patient-consumer was reconfigured by the Conservative government, and emphasis moved from the collective needs of patient-consumers to the rights of individuals within increasingly marketized services. This development thus raises questions not only about who speaks for the consumer, but also about the relationship between citizenship and consumption in contemporary Britain.
\end{abstract}

The notion that patients could be regarded as consumers was not a new one in Margaret Thatcher's Britain, but it was between I979 and I990 that the patientconsumer moved from the shadows to centre-stage. Book-ended by publication of the consultative paper, Patients first in I979, and creation of the internal market in I990, Thatcher's term as prime minister marked an era of 'continuous revolution' in health policy. ${ }^{1}$ The technocratic approach to health service delivery characteristic of the I960s and I970s was replaced with business methods and market mechanisms as the Thatcher government attempted to 'roll back' the state's direct involvement in public services. Within health care, the patient was placed at the figurative centre of this endeavour. Thatcher herself felt that 'there was too little sensitivity to the preferences and convenience of patients' in the health service, resulting in the establishment of a series of measures to put

Centre for History in Public Health, London School of Hygiene and Tropical Medicine, I5-I7 Tavistock Place, London,wCIH9sH alex.mold@lshtm.ac.uk

${ }^{1}$ Department of Health and Social Security (DHSS), Patients first: consultative paper on the structure and management of the National Health Service in England and Wales (London, I979); The National Health Service and Community Care Act (I990); C. Webster, The National Health Service: a political history (Oxford, 2002), pp. $140-207$. 
the interests of patients first. ${ }^{2}$ The 1983 Griffiths Management Enquiry proposed the introduction of managers into the National Health Service (NHS) to solicit opinion about services from consumers and 'secure the best possible services for the patient' (original emphasis). ${ }^{3}$ The White Paper, Working for patients, which proposed the creation of an internal market within the NHS in I989, aimed to extend patient choice and 'put the needs of patients first'.

The reforms introduced under Thatcher have been seen as a crucial stage in the NHS's transition from what Rudolf Klein described as the 'church' model (characterized by paternalism, planning, need, and universalism), towards the 'garage' model (typified by consumerism, responsiveness, demand, and choice). ${ }^{\mathbf{}}$ It was, however, also a critical moment in the remaking of the relationship between the state and citizen in Britain, as the supposed consensus around universal entitlements to welfare was eroded by the concept of individualistic rights to, and choice of, services. In a number of spheres, including housing, utilities, and health, publicly owned services were either privatized or re-designed, often along market principles. ${ }^{6}$ Citizens were being reconfigured as consumers, a development which moved emphasis away from the duty of the state to provide universal coverage, and towards the rights of individuals to make choices about the services that they used. ${ }^{7}$

Such a shift can partly be explained by the New Right's faith in the market as the most effective and efficient way of delivering services, coupled with Thatcher's dislike and distrust of professionals, and the corresponding view that individuals were best placed to decide what was in their own interests. ${ }^{8}$ Yet neo-liberal ideology and the introduction of market mechanisms was by no means the only way of applying consumerism to public services. Away from New Right think-tanks and the theories of health economists such as Alain Enthoven, alternative understandings of the patient as consumer were being produced. Generic patient groups, defined as organizations that aimed to represent all patients regardless of the conditions that they suffered from, or the population group to which they belonged, played a vital role in the making of the patientconsumer. Organizations such as the Patients Association (established in I962),

${ }^{2}$ M. Thatcher, The Downing Street years (New York, NY, I993), p. 607.

3 NHS Management Enquiry, 6 Oct. 1983 (Griffiths Report), reproduced in S. Harrison, National Health Service management in the Ig8os: policymaking on the hoof? (Avebury, I994), p. I75.

${ }^{4}$ Her Majesty's Stationary Office (HMSO), Working for patients (London, I989), Foreword by Margaret Thatcher.

5 R. Klein, The new politics of the NHS: from creation to reinvention (Oxford, 2006), pp. 253-5.

$6 \mathrm{P}$. Shapely, 'Tenants arise! Consumerism, tenants and the challenge to council authority in Manchester, I968-I992', Social History, 3I (2006), pp. 6o-78; A. Young, The politics of regulation: privatized utilities in Britain (Basingstoke, 200I).

7 On the broader relationship between citizenship and consumption, see F. Trentmann and K. Soper, eds., Citizenship and consumption (Basingtoke, 2008). On the continued making of the citizenconsumer under New Labour, see J. Clarke, J. Newman, N. Smith, E. Vidler, and L. Westmarland, Creating citizen-consumers: changing publics and changing public services (London, 2007).

${ }^{8} \mathrm{~J}$. Le Grand, Motivation, agency and public policy: of knights $\&$ knaves, pawns \& queens (Oxford, 2003). 
the Consumers' Association (1956), the National Consumer Council (1977), the Community Health Councils (1974), and the College of Health (1983), attempted to speak and act for patient as consumers throughout the I980s and I99os. By considering the work of such groups, this article demonstrates that the patient-consumer was not conjured into being by the Conservative government alone, but was the product of an interaction between patient groups, the state, the medical profession, and the affluent society.

Three interlinked themes were critical to the process: first, the collection, collation, and dissemination of information to patients; second, the development of patients' rights; and finally, the promotion of patient choice. Through their activities around information, rights, and choice, patient groups agitated for a greater role for individuals and the wider population in determining health policy and practice. In so doing, they created an identity that was collective as well as individual: patient groups were concerned with patient-consumers, as well as the patient-consumer. Such ideas met with limited success. Although many specific initiatives begun by patient groups, such as reports on the length of waiting lists, telephone advice lines, patients' charters, and rights guides, were adopted by the government, the broader values underpinning these programmes, encompassing collective as well as individualistic ways of applying consumerism to public services, were not. The tools used in the making of the patient-consumer by patient groups were co-opted by the Thatcher government and used to create a more individualized figure. The presence of such contrasting ideas about the meaning of patient consumerism thus raises broader questions not only about who spoke for the patient-consumer, but also about citizenship and consumption, about shifting relationships between professionals, the state, and citizens, and how people are 'made' in late modern Britain.

The 'making up' of people, the creation of subjects, objects, and identities, has been a fruitful avenue of historical and theoretical enquiry for many decades. Following Michel Foucault, numerous scholars have demonstrated that particular kinds of subjects were formed by scientific knowledge, expertise and regulation. ${ }^{\mathbf{9}}$ As biomedicine proliferated, so too did 'made up people', from the autistic to the obese. ${ }^{\mathbf{1 0}}$ The 'patient' as one party within the medical encounter has inevitably always existed, but there is debate about how this figure was constructed. Before I950, according to David Armstrong, the medical gaze focused on the lesion, rather than the patient. When the location of disease shifted away from the physical body to the social body, however, what patients had to say became

9 Foucault's most influential works in this context are M. Foucault, The history of sexuality, I: An introduction (Harmondsworth, I990), and Discipline and punish: the birth of the prison (New York, NY, I979). See also N. Rose, Governing the soul: the shaping of the private self(London, I999), and N. Rose, Inventing our selves: psychology, power and personhood (Cambridge, I996).

10 I. Hacking, 'Making up people', London Review of Books, 28 (I7 Aug. 2006), pp. 23-6. 
significant: 'illness was being transformed from what was visible to what was heard' ${ }^{11}$ The renewed importance attached to the patient's view allowed for a change in patienthood during the latter half of the twentieth century, placing fresh emphasis on patients' rights and representation. ${ }^{12}$ Yet for other analysts, particularly those concerned with the era before the dominance of biomedicine, the patient was always an active figure. Roy Porter suggested that the patient was not just the product of the medical gaze, but also an individual with a degree of autonomy and choice. ${ }^{13}$ More recent studies of the patient's position in a variety of periods and settings have stressed that recipients of health care were far from being 'passive in the face of whatever was put before them'. ${ }^{14}$ It should not, therefore, be assumed that individual agency disappeared with the development of biomedicine, but nor is it the case that patients were either autonomous individuals or powerless subjects. ${ }^{15}$ Expert forms of knowledge could combine with lay understandings, and individuals were able to adapt categories to their own ends.

Such a practice was not confined to the biomedical world; it can also be observed in the making of the consumer. As Frank Trentmann has argued, the consumer revolutions of the eighteenth and twentieth centuries did not automatically turn people into consumers; 'political synapses' were necessary to configure the consumer. Political traditions and languages came into effect which allowed individuals to connect material experiences with a sense of belonging, interest, and entitlement. ${ }^{16}$ More than one type of actor was involved in this process: as Matthew Hilton and Martin Daunton point out, the consumer interest was defined by an inter-play of political and business interests, varying kinds of expertise, and the activities of consumers themselves. ${ }^{17}$ What it meant to be a consumer also changed over time and place. In the early twentieth century, consumer identity was tied to the development of welfare politics and social citizenship, but by the middle of the century, the 'citizen consumer' and the 'rational consumer' came into being. ${ }^{18}$ During the I950s, the development of an organized consumer movement concerned with consumers' rights and comparative testing moved consumption 'beyond things', to consider public,

11 D. Armstrong, 'The patient's view', Social Science and Medicine, i8 (I984), pp. 737-44, at p. 739.

12 Ibid., p. 743 .

13 R. Porter, 'The patient's view: doing medical history from below', Theory and Society, I4 (I985), pp. I75-98.

14 A. Borsay and P. Shapely, eds., 'Introduction' to Medicine, charity and mutual aid: the consumption of health and welfare in Britain c. I550-1950 (Aldershot, 2007), p. I.

15 F. Condrau, 'The patient's view meets the clinical gaze', Social History of Medicine, 20 (2007), pp. 525-40.

${ }^{16} \mathrm{~F}$. Trentmann, 'The modern genealogy of the consumer: meanings, identities and political synapses', in F. Trentmann and J. Brewer, eds., Consuming cultures, global perspectives: historical trajectories, transnational exchanges (Oxford, 2006), pp. 19-69, at p. $5^{\circ}$.

17 M. Hilton and M. Daunton, 'Material politics: an introduction', in Daunton and Hilton, eds., The politics of consumption: material culture and citizenship in Europe and America (Oxford, 200I), pp. I-32, at p. 4 .

18 Trentmann, 'The modern genealogy', pp. $43^{-8 .}$ 
as well as private, goods and services. ${ }^{19}$ By the $1960 s$, health economists and consumer groups began to use the term 'consumer' in the context of health care and other public services. ${ }^{20}$

The application of consumerism to public services was not uncontested Raymond Williams grumbled about its 'overwhelming extension' to 'such fields as politics, education and health', and Margaret Stacey branded the patient-consumer a 'sociological misconception' - but the notion of the public service consumer gathered political and practical saliency. ${ }^{21}$ This can be seen in the development of a number of bodies and mechanisms to represent the consumer within public services, such as the establishment of the National Consumer Council (NCG) in 1975, and the creation of the Community Health Councils (CHCs) in I974. The form of consumerism manifested within the NCG and the CHCs could be seen as being largely synonymous with citizen participation, as part of an attempt to involve citizens more closely in decision making begun by Harold Wilson's first government. ${ }^{22}$ The Labour party's support for such initiatives was partly a response to challenges posed by the new social movements and the burgeoning voluntary sector, which exposed deficiencies in public services. ${ }^{23}$ Individuals diagnosed with specific diseases, particularly those suffering from conditions which they believed to be inadequately addressed by existing services, began to form groups to campaign for improvements. ${ }^{24}$ Although public satisfaction with the NHS remained high throughout the ig6os and I970s, a number of scandals, surrounding specific treatments such as the

19 M. Hilton, Consumerism in twentieth-century Britain: the search for a historical movement (Cambridge, 2003).

20 See, for example, D. S. Lees, Health through choice: an economic study of the British National Health Service (London, I96I); Political and Economic Planning, Family needs and the social services (London, I96I); Research Institute for Consumer Affairs, General practice a consumer commentary (London, I963); A. Cartwright, Human relations and hospital care (London, I964). A similar pattern of movement of the patient-consumer from health economists to consumer groups has been observed in the USA, see N. Tomes, 'Patients or health-care consumers? Why the history of contested terms matters', in R. A. Stephens, C. E. Rosenberg, and L. R. Burns, eds., History and health policy in the United States: putting the past back in (New Brunswick, NJ, 2006), pp. 83-IIo.

${ }^{21}$ R. Williams, Keywords: a vocabulary of culture and society (London, I976; I988 edn), p. 79; M. Stacey, 'The health service consumer: a sociological misconception', Sociological Review Monograph, 22 (I978), pp. I94-200.

22 S. Fielding, The Labour governments, 1964-1970, I: Labour and cultural change (Manchester, 2003), pp. I8-I9, I9I-208.

${ }^{23}$ H. Curtis and M. Sanderson, eds., The unsung sixties: memoirs of social innovation (London, 2004); N. Crowson, M. Hilton, and J. McKay, eds., NGOs in contemporary Britain: non-state actors in society and politics since 1945 (Basingstoke, 2009); A. Lent, British social movements since 1945: sex, colour, peace and power (Basingstoke, 200I).

24 A few studies of particular disease specific groups exist, see, for example, N. Crossley, 'Transforming the mental health field: the early history of the National Association for Mental Health', Sociology of Health and Illness, 20 (1998), pp. 458-88, and M. Nicholson and G. W. Lowis, 'The early history of the Multiple Sclerosis Society of Great Britain and Northern Ireland: a socio-historical study of lay/practitioner interaction in the context of a medical charity', Medical History, 46 (2002), pp. I4 $\mathrm{I}^{-}-74$, but further work is needed on the interaction between groups such as these and notions of health consumerism. 
prescription of thalidomide to pregnant women, and more general systems of care, principally for the elderly and mentally ill, drew attention to the fallibility of the health service and those who worked within it. ${ }^{25}$ This period also witnessed a broader assault on professional power, as medical sociologists and others questioned paternalistic assumptions and practices. ${ }^{26} \mathrm{~A}$ space for the autonomous patient-consumer appeared to be opening up, but the meaning, purpose, and nature of this figure was still up for debate when Thatcher came to power in I979.

\section{I}

A key factor in the making of the patient-consumer was the collection and dissemination of information to patients. Patient groups spent a large portion of their time and resources providing different kinds of information in various forms, involving both the diffusion of existing information and the creation of new knowledge. Much attention was devoted towards explaining to patients what services were available under the NHS and how they could be accessed. A plethora of patients' guides to the NHS were published during the I980s and I9gos, often framed around the notion of patients' rights, a theme discussed in more detail below. ${ }^{27}$ Practical advice was also provided by patient groups for dealing with specific illnesses and maintaining good health. The Consumers' Association (CA) published an extensive range of guides to common conditions such as heart disease, cancer, stress, allergies, backache, and mental illness which explained the nature of each disease, its causes, treatment, prognosis and prevention. ${ }^{28}$ Health-related topics also appeared in the pages of the CA's magazine, Which?. Articles offered advice to subscribers with specific conditions, such as the September 1983 feature 'Baldness in men - is there an answer?' as well as guidance on healthy living, such as the potential dangers of consuming alcohol. ${ }^{29}$ Health education and health promotion were also key features of the College of Health's $(\mathrm{CoH})$ journal, Self Health (later Which? Way to Health) which

${ }^{25}$ G. E. Appelbe, 'From arsenic to thalidomide: a brief history of medicine safety', pp. 243-6o, in S. Anderson, ed., Making medicines: a brief history of pharmacy and pharmaceuticals (London, 2005), pp. 253-7; Webster, The National Health Service, pp. 80, II9-2I.

${ }^{26}$ See, for example, I. Illich, Limits to medicine-medical nemesis: the expropriation of health (London, 1976); T. Szasz, The myth of madness: foundations of a theory of personal conduct (New York, NY, 1974); T. McKeown, The role of medicine: dream, mirage or nemesis? (Oxford, 1979); E. Goffman, Asylums: essays on the social situation of mental patients (London, I96I).

${ }^{27}$ For example Consumers' Association (CA), The Which? guide to your rights (London, 1980); CA/Patients Association (PA), A patient's guide to the National Health Service (London, I983); National Consumer Council (NCC), Patients' rights: a guide for NHS patients and doctors (London, 1983); R. Gann and S. Knight, College of Health consumers' guide to health information (London, 1986).

${ }^{28}$ CA, Avoiding heart trouble (London, I980); CA, Understanding stress (London, I988); CA, Understanding allergies (London, I986); CA, Understanding cancer (London, I986); CA, Understanding back trouble (London, I99I).

${ }_{29}$ 'Baldness in men: is there an answer?' Which?, Nov. 1983; 'Drink', Which?, Oct. 1984, pp. 445-9. 
considered, amongst other issues, the merits of wholemeal bread, cycling, and yoga. ${ }^{30}$

In addition, patient groups communicated information to individuals through non-text based media. A key outlet was the CoH's telephone information service, Healthline, established in I984. Healthline was a free service, providing callers with access to a collection of over 200 pre-recorded tapes on a wide selection of topics including heartburn, nervous breakdown, and the menopause. The switchboard received more than 7,00o calls in its first five months. ${ }^{31}$ The College felt that the service was particularly valuable in providing information on conditions that callers may have felt uncomfortable discussing with their doctors, such as HIV/AIDS. Indeed, this was a contention supported by the Department of Health and Social Security (DHSS), which gave the $\mathrm{CoH}$ a grant in 1985 to support their AIDS telephone information service. ${ }^{32}$

Healthline, and the various guides produced by the CA and other groups, clearly played an important role in providing patients with information about medical conditions and how to seek help for their treatment. Such work combined health education and health promotion. As CoH's founder and long-time consumer activist, Michael Young, noted in a report on Healthline, 'For health, information is of the essence. It is essential for prevention and it is essential for treatment. ${ }^{\mathbf{3 3}}$ Information also, however, held a wider significance for many patient groups: the provision of information was intended to empower patients. One of the CoH's main aims was 'to give people the information they need to approach the health services as active partners in health care not as passive patients' ${ }^{34}$ For other organizations too, informing patients was a way of changing doctor-patient relationships for the better. Katharine Whitehorn, chair of the Patients Association (PA), suggested in her Foreword to A patient's guide to the National Health Service that 'Doctors occasionally act as if patients getting hold of The Knowledge would threaten them almost as much as an apprentice getting hold of the sorcerer's spell book; but I think it's the other way round. Informed patients can actually be a huge help to the medical profession. ${ }^{35}$ For the NCG, the provision of information would allow patients to get the best from the health service. The chair of the NCG, Michael Shanks, pointed out that each family paid EI8 per week in 1983 towards the cost of the NHS but 'too many of us behave as if we are being given charity - there is a tendency towards passive acceptance of health services. This is not the way for patients to get the highest quality of

30 Self Health, Nov. I983; Self Health, Jan. I984; Self Health, Mar. I985.

31 M. Rigge, "Healthline": a new service from the College of Health', Health Libraries Review, 3 (I986), pp. I-IO.

32 Private papers of Michael Young, Churchill College Cambridge (YUNG) YUNG/6/Io/7, A. Williams, 'Very preliminary paper on the College of Health', 23 May i99i. See also V. Berridge, AIDS in the UK: The making of policy, I98I-I994 (Oxford, I996), pp. 89, I24.

${ }^{33}$ YUNG/6/27/2, M. Young, Healthline and Health Information Trust Report, I987.

34 YUNG/6/ro/ı, $\mathrm{CoH}(\mathrm{CoH})$ First Annual Report, ig84.

35 CA/PA, A patient's guide, p. 8. 
service. ${ }^{36}$ Informed patients, it was suggested, would be better at extracting maximum utility from the NHS, like the idealized consumer.

To strengthen the position of this patient-consumer, patient groups went beyond providing information that drew on existing sources and began to create new kinds of knowledge about health and the health service. For the groups most closely tied to the consumer movement, like the $\mathrm{CA}$ and the $\mathrm{CoH}$, this meant subjecting goods and services to comparative testing. Throughout the I980s and I99os, Which? reported the results of comparative analysis of health-related services such as opticians, private medical insurance, and allergy testing, and products including denture cleaners and fixatives, painkillers, and condoms. ${ }^{37}$ Results of the condom test were simultaneously published in Self Health in September 1987, at the height of concern about the transmission of HIV/AIDS, and revealed that several brands of condoms contained small holes. ${ }^{38}$ The critical appraisal of products by consumer groups, as Matthew Hilton has noted, was central to the development of a kind of 'super-shopper', an efficient, rational, scientific, and discriminating individual able to decide what to consume on the basis of objective information. ${ }^{39}$

Elements of this approach were clearly present in the testing of health services and products, but a broader figure than the 'super-patient' was being envisaged by the CA and other organizations. The $\mathrm{CA}$, the $\mathrm{CoH}$, and many of the 207 locally based CHCs, surveyed patients' views of services and attempted to identify where services were failing, establish how these could be improved, and consider how inequalities in service provision could be addressed. The survey was a key tool for the CHCs in particular; some of whose surveys identified a need for new facilities. ${ }^{40}$ A study conducted by Central Birmingham CHC in 1979, for example, pointed to the need for an interpreter at several city hospitals to enable staff to communicate with Asian patients. ${ }^{41}$ Surveys could also point to failings in existing services: Tameside CHC reviewed local psychiatric facilities and concluded that although the shift towards outpatient provision was justified, better co-operation between services and more resources were required. ${ }^{42}$ Furthermore, CHC surveys highlighted the significance of wider issues in health care provision. South Gwent CHC, for example, conducted a survey in 1984 that

\footnotetext{
36 NCG, Patients' rights, p. 3 .

37 Which?, Mar. I983; Which?, June I984; Which?, Jan. I987; Which?, Jan. I983; Which?, Feb. I986; Which?, Sept. 1987.

38 Self Health, I6 (Sept. I987); interview between author and M. Rigge, io Mar. 20 Io.

${ }^{39}$ M. Hilton, 'The fable of the sheep, or private virtues, public vices: the consumer revolution of the twentieth century', Past and Present, I76 (2002), pp. 222-56, at p. 238.

40 Association of Community Health Councils for England and Wales (ACHCEW), The golden age of patient and public involvement: celebrating the work of the Community Health Councils, CD Rom, vol. 2, ACHCEW, The consumers view: a review of CHCs surveys on outpatient departments (London, I984).

${ }^{41}$ Central Birmingham CHC, Annual report, i June 1979-3i May i980.

42 ACHCEW CD Rom, Vol. 2, Community Health News, Feb./Mar. I985, p. Io.
} 
examined the effect of socio-economic conditions on the health of people living in a housing estate on the outskirts of Newport. ${ }^{43}$

Finding out what patients thought of services became more common during the I980s, particularly following the $\mathrm{I}_{9} 8_{3}$ Griffiths enquiry into management in the NHS and the introduction of general management to the health service. One of the chief responsibilities of newly installed managers was to assess consumers' views of services and to adjust services accordingly. ${ }^{44}$ The most common way of achieving these aims was through patient satisfaction surveys. ${ }^{45}$ For groups like the $\mathrm{CoH}$, however, patient satisfaction surveys did not go far enough. Critical of what it regarded as a 'tick box' approach to determining levels of patient satisfaction, the College developed what it saw as a more comprehensive approach, called consumer audit, towards the end of the ig8os. ${ }^{46}$ Paralleling the increasingly common medical or clinical audit, a process by which clinicians examined each other's work and practices, and also Social Audit, an independent organization with links to the consumer movement, consumer audit involved in-depth interviews with patients and staff at all levels. ${ }^{47}$ The $\mathrm{CoH}$ asserted that 'The whole purpose of consumer audit is to make the processes of health care more responsive to the rightful expectations of the user. ${ }^{48}$ Funded initially by the Nuffield Provincial Hospital Trust and the King's Fund, the College was contracted by numerous hospitals to audit services, suggesting that NHS managers also saw the value of the CoH's approach. ${ }^{\mathbf{4 9}}$

Managers were less welcoming, however, of another type of information gleaned by the $\mathrm{CoH}$ : data on the length of hospital waiting-lists. Based on returns made by District Health Authorities to the DHSS, the CoH published its first Guide to hospital waiting lists in I984. ${ }^{\mathbf{5 0}}$ The Guide found that there were more than 700,000 people waiting for admission to hospital. Moreover, the DHSS's objective that urgent cases should wait no longer than a month for admission, and nonurgent cases no more than a year, was not being met. In I984, 30,000 urgent cases had been waiting longer than a month, and 205,00o non-urgent cases had waited for longer than a year. ${ }^{51}$ Subsequent guides also highlighted the fact that there was considerable regional variation in waiting times, and that patients could get treated faster if they 'shopped around': 'We hope that by publishing this Guide we can help patients and their GPs make effective use of the NHS by seeking

${ }^{43}$ ACHCEW CD Rom, Vol. 2, Community Health Newes, Nov. 1984, p. I3.

${ }^{44}$ Harrison, National Health Service management in the 1980s; M. Gorsky, ed., The Griffiths NHS management enquiry: its origins, nature and impact (London, 2010).

${ }^{45}$ C. Batchelor, D. J. Owens, M. Read, and M. Bloor, 'Patient satisfaction surveys: methodology, management and consumer evaluation', International Fournal of Health Care and Quality Assistance, 7 (1994), pp. $22-30$.

${ }^{46}$ YUNG/6/Io/II, CoH Information Leaflet, n.d [199os?]; M. Rigge, 'Involving patients in clinical audit', Quality in Healthcare, 3 (1994), supplement, pp. 2-5.

${ }^{47}$ C. Medawar/Social Audit, The wrong kind of medicine (London, I984).

${ }^{48} \mathrm{YUNG} / 6 / \mathrm{ro} / 7$, 'The patient speaks: good practice in consumer relations in the health service', by M. Young and the staff of the CoH, Mar. I99I. $\quad{ }^{49}$ Interview between author and Rigge.

${ }^{50}$ Ibid.

${ }^{51}$ YUNG/6/1o/ıo, CoH First Annual Report, I984. 
treatment in another health district if they find an excessively long waiting list. ${ }^{\mathbf{5 2}}$ But the College did not just want to help individual patients to get treated faster; they wanted to use regional variation in waiting times to make a broader point about inequality within the NHS. The I989 Guide asserted that 'From the start ... our concern has been that people should be treated with greater equity. As things are it still seems to be almost a matter of geographical accident whether patients find themselves on a long waiting list or a short one.' 'Fairness', the Guide continued, 'is the basic principle of the NHS. It could and should be extended. ${ }^{\mathbf{5 3}}$

The CoH's interest in issues of equity suggested that it saw the patientconsumer both as an individual and as part of a wider community of health service users. The College of Health and other groups, especially the CA, cultivated a view of the patient-consumer as a rational, informed, health-conscious individual. Information was a way of empowering patients and transforming the doctor-patient relationship. Moreover, this figure was not just a 'super-patient', but also a self-governing subject of the new public health, concerned with maintaining a 'healthy' lifestyle. ${ }^{54}$ At the same time, groups like the $\mathrm{CoH}$ believed that information should do more than create healthy super-patients: information was a way of putting pressure on the government and health service managers to improve the quality and equality of services. This was a broader view of the role of information and also of the nature of the patient-consumer than that being proposed by the Thatcher government. The tools developed by patient groups to collect and disseminate information, such as patient surveys and advice lines, were taken on by the government, but put to rather different uses. The information gathered empowered managers, not patients, to make decisions. Few attempts were made to pass more information on to patients themselves; rather, it was left to managers to act as 'proxy consumers', making choices on the behalf of patients. By contrast, patient groups wanted consumers themselves to use information to make better choices about their own care, but at the same time information was also vital to their aim to improve care for all. Information helped to produce patient-consumers, as well as the patient-consumer.

\section{I I}

Individual and collective views of the patient-consumer, and the tensions between these two approaches, were also evident in the development of patients' rights by patient groups. The idea that patients were in possession of certain rights was not a new one - in the Ig6os, the PA had campaigned for the right of patients to consent to participate in medical experiments and to being examined by medical students - but during the I980s and early I99os, the rights discourse appeared to

52 YUNG/6/Io/I2, CoH, College of Health guide to hospital waiting lists, 1987, p. 3.

$53 \mathrm{YUNG} / 6 / \mathrm{Io} / \mathrm{I} 2, \mathrm{CoH}$, Guide to hospital waiting lists, I989, pp. I-2.

54 A. Petersen and D. Lupton, The new public health: health and self in the age of risk (London, 1996); I. Shaw and A. Aldridge, 'Consumerism, health and social order', Social Policy and Society, 2 (2003), pp. $35^{-43}$. 
proliferate. ${ }^{\mathbf{5 5}}$ Patient organizations drew on the language of rights to put forward claims in areas such as access to health care, consent to treatment, complaining. and access to medical records. These claims were set out in numerous patients' rights guides and charters published by patient groups in the Ig8os. Documents outlining patients' rights were produced by the NCC, the CA, the PA, the CoH, and the umbrella body for the CHCs, the Association for Community Health Councils in England and Wales (ACHCEW). Guides such as the NCC's Patients' rights, published in ${ }^{1} 8_{3} 3$, set out patients' rights with respect to areas including access to services and information, consent, representation, and complaining. ${ }^{\mathbf{5 6}}$ Other texts, like A patient's guide to the National Health Service, which was produced jointly by the CA and the PA also in $198_{3}$, detailed patients' rights alongside information about how to access specific types of service, such as dentistry, optometry, mental health, and maternity services. ${ }^{\mathbf{5 7}}$

The employment of the language of rights by patients' guides was clearly intended to strengthen the patient's position. Like information, rights would help empower the individual. As the Foreword to A patient's guide asserted 'if we knew what our rights were; if we knew how to complain, and to whom; if we knew what could be expected of our doctors and nurses and what should not be expected of them; then, I believe, a good deal of trouble would be controllable' ${ }^{58}$ Similarly, the NCC's Patients' rights contended that 'patients will get the best from the health service only when they know what is reasonable to expect of it, what their rights and responsibilities are and when they have the confidence and skill to exercise them ' ${ }^{59}$ Yet, despite the apparent power of the language of rights expressed by patient groups, there was considerable uncertainty about the status of such rights, about their legal standing, and whether such rights should apply to individuals, or to the whole population. The NCG stated that 'It is difficult to say precisely what health care patients are entitled to expect of the National Health Service (NHS). There are clues, but most of them are open to different interpretations, and circumstances greatly affect cases. ${ }^{\mathbf{6 0}}$ This was partly because, as the CA observed in its guide to consumers' rights across a range of different services, that

There is no comprehensive list of rights which you can consult, nor is there any specific area of law that deals with them. Your rights are scattered among hundreds, perhaps thousands, of Acts of Parliament and secondary pieces of legislation ... Sometimes your rights are not written down at all. They may exist because of custom and tradition, or merely because there is nothing saying that they are absent. ${ }^{61}$

55 Contemporary Medical Archive Centre, Wellcome Library (CMAC), Papers of the Medical Women's Foundation, SA/MWF/H.23, Press Release from the PA: 'Patients association attacks Minister of Health as misleading on the use of patients as teaching material', 5 Apr. I968; Anon., 'Now a voice for patients', Times, I7 June I963, p. I5; H. Hodgson, 'Medical ethics and controlled trials', letter to the British Medical fournal, i8 May i963, pp. I339-40.
56 NCG, Patients' rights.
59 NCG, Patients' rights, p. 3.
$57 \mathrm{CA} / \mathrm{PA}, A$ patient's guide.
58 Ibid., p. 7 .
61 CA, The Which? guide to your rights, p. 9. 
Indeed, the legal status of many rights claimed for patients was highly questionable. Only three rights had any basis in law: these were the right to consent; the right to complain and the right to access medical records. The right to consent emerged through case law, and although there was no single law requiring individuals to give consent to medical treatment, by the late I980s, it was generally accepted that informed consent was required, particularly for surgery. ${ }^{62}$ The right to complain was brought in through the Hospital Complaints Procedure Act (I985) which made it compulsory for health authorities in England and Wales and health boards in Scotland to establish a complaints procedure and to draw this procedure to the attention of patients. ${ }^{63}$ The right to access medical records was introduced through two pieces of legislation - the Data Protection Act (I984) and the Access to Health Records Act (I990) - which gave patients the right to see their own computerized and paper medical records. ${ }^{\mathbf{6 4}}$ Patient groups played a role in securing all of these rights, but as the campaign for the right to access medical records illustrates, the actual formation of legislation in each case was due to a complex mixture of factors.

Organizations like the PA had long believed that 'the patient should have the absolute right of access to his medical notes', but it was Britain's obligations under the Council of Europe's Data Protection Convention in I98I that created an opportunity for greater openness. ${ }^{65}$ The convention mandated that individuals should have access to information held about them, leading to the introduction of the Data Protection Act in I984. The act, however, was unclear about whether or not medical records should be exempted from the principle of subject access, so the DHSS began a consultation exercise with doctors and patient groups. Sections of the medical profession were opposed to giving patients the right to see their records: Dr Maurice Burrows, chairman of the British Medical Association's Central Committee for Hospital Medical Services, asserted that " "We are not saying patients should have no access to their records. If a doctor wants to [allow access] that's okay but we don't want to see a legal right to it." ",66 Patient and consumer groups, in contrast, thought patients should have an absolute right to see their records. In their evidence to the DHSS the NCG stated that 'subjects should have the same access to their personal health data as to any other personal data' ${ }^{67}$ The Department eventually pursued a middle path,

\footnotetext{
62 A particularly influential assertion of the importance of patient autonomy and informed consent during the I980s, and in the decades since, was T. Beauchamp and J. Childress, Principles of biomedical ethics, first published in I979, and now into its sixth edition.

63 Hospital Complaints Procedure Act (1985).

64 Data Protection Act (I984); Access to Health Records Act (I990).

65 The National Archives, HO 26r/265, the Data Protection Committee: Medical Records. Note by the Patients Association, I9 Dec. I976; Council of Europe, Convention for the protection of individuals with regard to automatic processing of personal data, European Treaty Series no. I08 (Strasbourg, I98I).

${ }^{66}$ CMAC, Papers of the Patients Association (SA/PAT) SA/PAT/K/2/I/II, 'Data decision', Hospital Doctor, I3 Feb. I986.

${ }^{67}$ CMAC, SA/PAT/K/2/I/II, Data Protection Act: Subject Access to Personal Health Information. Response of the NCG, Feb. I986.
} 
enabling doctors to withhold records from patients if the information contained within them was thought 'likely to cause serious harm' to the physical or mental health of the patient, but a right of access to computerized, and later paper-based records, was confirmed in principle. ${ }^{68}$ The long campaign by patient groups for greater openness in the doctor-patient relationship had clearly paid off, helping to create a sense within the DHSS that patients were entitled to some degree of access to their records. ${ }^{69}$ Whether such legislation would have come to pass without the additional impetus of the European Union directive on data protection, and the tacit support of at least some of the medical profession is, however, open to debate. For patients' rights to gain legal force, the support of other actors was plainly required.

Legal interpretations were just one way of defining patients' rights and legalistic notions of rights have often been criticized as being too narrow in focus. ${ }^{\mathbf{7 0}}$ Alternative ways of grounding patients' rights were available to patient groups at the time, including notions of social rights, consumer rights, and human rights. The idea of social citizenship put forward by T. H. Marshall in I949 was based around social rights which included the "right to a modicum of economic welfare and security' ${ }^{\mathbf{7 1}}$ To an extent, social rights were incorporated within the post-war welfare state, which promised universal access to comprehensive services, but key pieces of legislation, such as the National Health Service Act (1946), were framed around the duty of the minister of health to provide a comprehensive service, rather than the right of the patient to receive this service. ${ }^{72}$ A more actionable type of rights claim seemed to be provided by the language of consumer rights. As Hilton has suggested, the consumer movement was based on the notion of rights to safety, to be informed, to choose, and to be heard. ${ }^{73}$ The problem for patient groups was that this language of rights was primarily focused on the individual and the protection of his/her interests in the marketplace, which was useful for their work with individual patients, but less relevant to broader, communal goals.

Notions of a collective right to health had deep roots : health was listed amongst some of the earliest proclamations of human rights in the eighteenth century, and during the second half of the twentieth century, health as a human right came to acquire global significance. ${ }^{74}$ The right 'to the enjoyment of the highest attainable

${ }^{68}$ DHSS, Data Protection Act 1984: modified access to personal health information (London, 1987).

${ }^{69} \mathrm{CMAC}, \mathrm{SA} / \mathrm{PAT} / \mathrm{K} / 2 / \mathrm{I} / \mathrm{II}$, Data Protection Act: subject access to personal health information - a consultation paper by the DHSS, 1985 .

70 T. Pogge, World poverty and human rights (Cambridge, 2008).

${ }^{71}$ T. H. Marshall, 'Citizenship and social class', in T. H. Marshall and T. Bottomore, Citizenship and social class (London, 1992), p. 8.

729 \& io George VI, c. II, 'The National Health Service Act' (1946).

${ }^{73}$ M. Hilton, 'The duties of citizens, the rights of consumers', Consumer Policy Review, I5 (2005), pp. 6-I2.

${ }^{74}$ D. Porter, Health civilisation and the state: a history of public health from ancient to modern times (London, I999), p. 57; M. Mazower, 'The strange triumph of human rights, I933-I950', Historical fournal, 47 (2004), pp. 379-98. 
standard of physical and mental health' was central to the establishment of the World Health Organization in I946, and the right to health was confirmed by the United Nations Universal Declaration of Human Rights in I948, and also the International Covenant on Economic, Social, and Cultural Rights, which came into effect for member countries in $1976 .{ }^{\mathbf{7 5}}$ Following the Alma Ata Declaration on Primary Care in 1978, the international public health movement began to campaign for the right to health on a global stage. ${ }^{76}$ In the ig8os and ig9os, key activists framed the international response to HIV/AIDS within a human rights context. $^{77}$

Despite a considerable level of activity around health as a human right, it seems that generic patient groups in the UK did not draw explicitly on such an agenda ${ }^{78}$ Little direct reference to the notion of health as a human right can be found in the papers and publications of patient groups during the I98os and I99os, although the human rights discourse did exert some impact on their activities. The notions of informed consent and patient autonomy, for example, were clearly related to a wider understanding of bodily integrity rooted within the language of human rights. ${ }^{79}$ Some of the work of patient groups also paralleled activities pursued by the international public health movement, which were rooted in the right to health, such as the CoH's interest in the development of health action areas, its concern with health inequalities, health education, and community participation. ${ }^{80}$ For many patient organizations, however, this collective approach to the notion of patients' rights sat uneasily alongside other, more individualistic, descriptions. It was often unclear whether such groups were concerned with the rights of the individual patient, or the rights of all patients, as can be seen in the charters and rights guides produced by patient groups. Some texts were clearly addressed to the individual: such as the Which? Guide to your rights, and the CA and PA's, A patient's guide. Yet others seemed to concern all patients: as in the NCG's Patients' rights, and ACHCEW's Patients' charter. Patient groups seemed uncertain whether to place rights in an individual or a collective context, a distinction which had practical, as well as theoretical, consequences.

75 United Nations, Universal declaration of human rights, Article 25 (1948), World Health Organization, Constitution of the World Health Organization (New York, NY, I946); United Nations, International covenant on economic, social and cultural rights (New York, NY, I966/I976).

76 Declaration of Alma Ata: international conference on primary health care (Alma Ata, I978).

77 A. Birn, 'Special section - health and human rights: historical perspectives and political challenges', Fournal of Public Health Policy, 29 (2008), pp. 32-4I; K. Cmiel, 'The recent history of human rights', American Historical Review, Iog (Feb. 2004), pp. I I7-35; S. P. Marks, 'The evolving field of health and human rights: issues and methods', Journal of Law, Medicine and Ethics, 30 (2002), pp. 732-54; D. Tarantola, 'A perspective on the history of health and human rights: from the Cold War to the Gold War', Journal of Public Health Policy, 29 (2008), pp. 42-53.

78 The language of human rights was important to some disease specific groups, such as those concerned with HIV/AIDS, especially at the international level. See Berridge, AIDS in the UK, pp. I62-3. $\quad{ }^{79}$ O. O'Neill, Autonomy and trust in bioethics (Cambridge, 2002).

80 YUNG/6/1o/4, Proposal to establish a Health Action Area for Pimlico: application for funds and support, I June I987. 
Reconciling an individual's right to receive an expensive service, for example, had to be balanced with the collective rights of the wider population within a state-funded health system with finite resources.

Drawing on the language of rights clearly presented patient groups with problems as well as opportunities. Underlying such difficulties was a lack of clarity about the nature of rights being claimed. If the rights advocated by patient groups were not necessarily analogous with legal rights, social rights, consumer rights, or human rights, what kind of rights were they? Without a clear basis, it was uncertain what was being claimed of whom, which left the patients' rights agenda open to co-option by other actors, most significantly the state, as seen in the production of the Department of Health Patient's charter in 1991. ${ }^{81}$ Lack of clarity about the nature of the rights being claimed should not, however, obscure its rhetorical power and practical significance. Patients' rights guides were intended to give patients a sense of their entitlements, and also to act as a form of protection. The vague nature of patients' rights allowed groups to lay claim to rights that did not yet exist, such as the right to a second opinion, and to make new kinds of demands, particularly as the language of rights began to combine with the notion of choice.

\section{V}

The concept of choice was central to the understanding of the rational consumer developed by consumer groups such as the CA, but the meaning of choice, and its implications within the context of health, was open to debate. ${ }^{82}$ For many patient groups, information, rights, and choice were inseparably bound together. The NCG contended that 'Choice and information are the life-blood from which other consumer rights flow. ${ }^{83}$ Similarly, director of the $\mathrm{CoH}$, Marianne Rigge, asserted that 'Without information there can be no real choice and I hope that the days are long gone when patients were not expected to exercise choice but rather follow the doctor's orders blindly. ${ }^{84}$ Through the trinity of information, rights, and choice, patients would become consumers. Michael Shanks, chair of the NCG, wanted 'consumers to be enabled to stand on their own feet and exercise their rights as individuals. In order to do this, they need to be able to exercise choice in an informed way. ${ }^{85}$

As patient groups were quick to point out, however, the capacity for patients to exercise choice within the NHS during the ig8os was very limited. Patients could choose their General Practitioner (GP), but 'It has often been one of the odder mysteries of life in this country that it is very difficult to get simple, factual

81 Department of Health, Patient's charter (London, I99I). The significance of the Patient's charter will be discussed in greater detail below. $\quad{ }^{82}$ Hilton, Consumerism in twentieth-century Britain.

$83 \mathrm{NCC}$, Annual report and accounts, I981/1982 (London, I982), p. 2.

${ }^{84} \mathrm{YUNG} / 6 / \mathrm{I} / 3$, 'Information and choice for patients', talk at King's College Hospital Medical School, 9 Sept. I986 [by Marianne Rigge].

85 NCC, Annual report and accounts, $1983 / 1984$ (London, I984), p. 8. 
information about the choice of general practitioners in your area. ${ }^{86}$ To encourage patients actively to choose their GP, Young proposed introducing a voucher system, whereby all NHS patients would be issued with a voucher to give to their preferred GP each year. ${ }^{87}$ Moreover, choosing a GP was not enough: other kinds of choices for patients were also envisaged. The $\mathrm{CoH}$ asserted that 'Active participants in health care must be able to make their own choices. ${ }^{88}$ The kinds of choices discussed by patient groups ranged from small-scale decisions about peripheral services, such as greater choice of food in hospital, to more significant choices about treatment and service provision. ${ }^{89}$ Central Birmingham CHC, for example, argued that patients should be able to make informed choices about their own health care and the extent to which they wanted to participate in it: 'We believe that a patient should be able to choose whether to hand over all decision-making to the doctor. ${ }^{90}$ Other kinds of choices were also envisaged: a survey published by Which? in 1989 suggested that seven out of ten patients thought it important to be able to choose which hospital to be referred to for specialist treatment. ${ }^{91}$

At the same time as stressing a need for greater capacity for individual choice, some groups also considered the implications of choice for the wider population. The NCG asserted that it made sense for certain services to be provided publicly because "the mechanisms of individual choice operating in the market place do not lead to the outcome which best serves the interests of all the individuals who constitute society' ${ }^{92}$ For services such as health care, where 'provision should be related to need and not payment', the 'individualistic mechanisms of the market' were not appropriate, but that did not mean that choice could not, or should not, be introduced into the NHS. ${ }^{93}$ Instead, the NCG proposed that greater choice be provided by offering variety in services, although this would, it conceded, have considerable cost implications. Choice, the Council suggested, should be provided at the collective, not solely individual, level. ${ }^{94}$ Similarly, whilst groups like Central Birmingham CHC called for greater individual choice, emphasis was also placed on collective representation by arguing that 'The notion of community participation in health care is an idea whose time has come. It is part of a movement towards a more open, democratic way of planning and organising society. ${ }^{95}$

${ }^{86}$ NCC, Annual report and accounts, 1987 (London, I987), p. 8.

${ }^{87}$ Lord Young of Dartington, 'The College of Health's view', pp. 27-46, in D. Green et al., The NHS reforms: whatever happened to consumer choice? (London, I989), p. 34.

88 YUNG/6/Io/Io, Gann and Knight, College of Health consumers' guide to health information, p. 3.

89 Aylesbury Vale Community Health Council (CHC), for example, surveyed hospital inpatients and found that patients wanted more choice of food. See ACHCEW, Community Health News, 47 (Oct. I989), p. I4. $\quad 90$ Central Birmingham CHC, Report, I June I979-3i May I980.

${ }^{91}$ Anon., 'Doctor, doctor: you and your GP', Which?, 32 (Oct. I989), pp. 48 ${ }^{-}{ }^{-5}$.

$92 \mathrm{NCC}$, The consumer and the state: getting value for public money (London, I979), p. I5.

93 Ibid., p. 62.

95 Central Birmingham CHC, Annual report, i June i979-3i May i980. 
Further questions were raised by patient groups about choice and health in relation to publication of the White Paper, Working for patients, in 1989 and the subsequent introduction of the internal market in 1990. The critique offered by patient groups pursued two ostensibly contradictory lines: on the one hand, choice was portrayed as potentially damaging, and on the other, that the reforms did not go far enough and that more choice should be made available to patients. Julia Neuberger, chair of the PA, pointed out that, under the new arrangements, there would be a perverse incentive for fund-holding GPs not to take on sicker, and therefore more expensive, patients. She argued that

it will be the case that middle-aged patients will have a greater choice of GP, as will all those categories who use the GP service relatively little. But those who use the service a great deal will be at a disadvantage. They may find it extremely hard to change doctors. ${ }^{96}$

Young also pointed out that not all patients would be able to make choices all of the time. In an emergency, he suggested, patients would rarely have any choice as to where they were admitted, but 'Patients who are frightened, at their most vulnerable and in pain should be able to feel confident about the quality of care they can expect to receive in any [his italics] NHS hospital. ${ }^{97}$ For other groups, it was the nature of choices being offered, and the market-based model in which such choices were to operate, that was problematic. West Essex and District CHC passed a resolution in 1989 expressing concern about what it saw as an 'over emphasis on the market place philosophy' within Working for patients, and the lack of democratic accountability inside the new system. ${ }^{98}$

Such a critique of choice was not necessarily at odds with the stance of the organizations that wanted more choice. Even groups that advocated greater choice did not seem to believe that the choices offered within Working for patients were the right ones: indeed, the advocates and critics of choice (as outlined in the White Paper) were often one and the same. The chief criticism was that the reforms did not offer any more choice to patients; indeed, these may actually have limited available choices. Under the new system, so-called 'purchasers' of health care (fund-holding GPs) would be able to control their own budgets and decide on the 'providers' (hospitals) to which their patients should be sent. As a Which? report on the reforms noted, the GP, not the patient, would choose which hospital to use, and this decision could be based on budgetary considerations as much as the patient's convenience. ${ }^{99}$ For the $\mathrm{CoH}$, 'It is not the patients who will have more choice, but some of the doctors and some of the managers.' As a result 'the White Paper will further enhance not the power of the consumer but the power of the producer and provider'. ${ }^{100}$ In similar vein, Neuberger contended that patients 'have little power to make their views felt, and that although the

${ }^{96} \mathrm{~J}$. Neuberger, 'A consumer's view', in Green et al., The NHS reforms, pp. 15-25, at p. I9.

${ }^{97}$ Young, 'The College of Health's view', in Green et al., The NHS reforms, p. 39.

98 ACHCEW CD Rom, Vol. 2, Community Health News, supplement on working for patients, issue 48, Nov. I989, p. 4 . ${ }^{99}$ Anon., 'Doctor, doctor: you and your GP', pp. $4^{8 \mathrm{I}^{-}} 5$.

100 Young, 'The College of Health's view', p. 28. 
White Paper claims to be about giving patients choice, they in fact get little more choice in GPs that they have before and considerably less choice beyond that stage' ${ }^{101}$ The CoH suggested that, instead of bolstering the power of doctors and managers, the NHS should be more responsive to what patients wanted, through mechanisms such as an improved complaints system, consumer audit, and the introduction of standards. ${ }^{\mathbf{1 0 2}}$

The vision of the patient-consumer presented by groups like the College of Health would seem, therefore, to have extended beyond the government's concept of this figure in two ways. Patient groups wanted more real choice for consumers but, on the other hand, were also aware of the potentially negative consequences of giving patients more choice, especially within a communal system with limited resources. Such a view was underpinned by an understanding of the patient-consumer that was both collective and individualistic: patient organizations were concerned with the information, rights, and choices made available to patient-consumers as a whole, as well as the sole patient-consumer.

\section{$\mathrm{V}$}

The publication of the Patient's charter by the Department of Health in I99I provides a clear indication of the distance travelled by the patient-consumer during Margaret Thatcher's term in office. Though the Patient's charter was the work of Thatcher's successor, John Major, it seemed to encapsulate many of the ideas concerning the patient-consumer advanced by patient groups during the I98os. Indeed, the entire notion of a charter setting out patients' rights to services and information drew on the model of earlier charters and rights guides produced by patient organizations. The Patient's charter endorsed seven 'well-established' rights and introduced three 'new' rights. The list of existing rights reformulated existing entitlements for patients (such as the receipt of health care on the basis of clinical need, rather than the ability to pay) into rights, and combined these with additional issues for which patient groups had long campaigned, such as the right to access medical records. The list of new rights established by the Patient's charter also appeared to reflect the wider activities of patient groups, as these rights related to issues such as the provision of detailed information on health services, including the length of waiting lists, guaranteed maximum waiting times, and the prompt investigation of complaints. ${ }^{103}$

But the publication of the Patient's charter was no victory for patient groups. Although the charter appeared to satisfy many demands made by patient organizations during the Ig8os, groups were 'suspicious' of the government's co-option of their campaigning language, and were dissatisfied with the charter and its contents. ${ }^{\mathbf{1 0 4}}$ Young contended that the Patient's charter was a 'great

\footnotetext{
101 Neuberger, 'A consumer's view', p. 24.

102 Young, 'The College of Health's view', pp. 42-5.

103 Department of Health, Patient's charter.

104 G. Hogg, Patients, power and politics: from patients to citizens (London, I999), p. 43.
} 
disappointment' that ' $\mathrm{t}$ ] alk about patients' rights will get us nowhere without the means to make the rights effective' ${ }^{105}$ According to ACHCEW, the charter should have done 'far more to address important issues at the heart of the health service - equality of access to health care, the scope for patient participation on the basis of informed choice and the quality of care and treatment'. ${ }^{106}$ The Patient's charter, with its emphasis on the rights of the patient, rather than the rights of all patients, appeared to be concerned with the individual patient-consumer, not with rights for all.

Such a focus on the individual represented a rejection of the more collective aspects of patient consumerism put forward by patient groups throughout the I980s and ig9os. Borrowing the tools of information, rights, and choice from patient groups, the Thatcher government and its successors set about creating an individualized patient-consumer designed to operate within increasingly marketized public services. Patient groups began to lose control of the figure that they had created. For patient groups, this was a double defeat. First, the part played by patient organizations in representing patients diminished as alternative, government-sponsored forms of soliciting individual patient's opinions (such as satisfaction surveys and citizens' juries) came to the fore. Speaking for the patient-consumer became a task for government, an irony which suggests that Thatcherism was not so concerned with 'rolling back the state' as reinventing new roles for it. Second, the broader view put forward by patient organizations concerning citizens' collective entitlements was undermined. The marketization of the NHS that began under Thatcher, but continued under Major, Blair, and Brown, added greater weight to individual choice at the expense of collective voice. Given Thatcher's commitment to the individual as an agent of change, and her infamous distaste for society, the failure of patient groups to convince her government of a collective view of the patient-consumer was understandable. Although patient organizations had the ear of policy makers, the contradictory logic of some of their arguments, particularly around the meaning and application of patients' rights, resulted in a message that lacked clarity. This allowed the government the freedom to pick and choose from the ideas put forward by patient groups. Patient organizations also failed to gain much political purchase: they were never able to mobilize large-scale popular support, and they were forced to occupy a subordinate position, when compared to the medical profession, within the health policy community. ${ }^{107}$

Yet, the Thatcher government's focus on the individual patient was not the inevitable consequence of reconfiguring patients as consumers. The work of

105 YUNG/6/10/7, Young's comments on the patient's charter to D. Brindle and M. Dean at the Guardian, n.d. [I99I].

106 ACHCEW CD Rom, Vol. 2, ACHCEW, The patients' agenda: what the patient's charter leaves out - the rights you don't yet have in the NHS (London, I996).

${ }^{107}$ On the relative power of the medical profession and patient groups in contemporary Britain, see B. Salter, 'Patients and doctors: reformulating the UK health policy community', Social Science and Medicine, 57 (2003), pp. 927-36. 
patient groups demonstrated that consumerism could draw attention to the needs of the many, as well as the demands of the few. Consumerism was about pursuing basic needs as well as luxuries, as could be seen in the expansion of the global consumer movement which concerned itself with wider issues during this period, such as those surrounding poverty, the environment, and access to pharmaceutical drugs. ${ }^{108}$ Combining consumers' rights to information and choice with the social rights of citizenship could have afforded the individual a greater say without undermining the security of collective entitlement. Indeed, the collective vision of patient organizations, with their emphasis on the needs of the wider population, never entirely disappeared from the horizon. The NHS remained a national service funded through general taxation, despite some calls to privatize health care. ${ }^{109}$ No doubt this was partly because the general public continued to be deeply attached to the collective nature of the NHS, but even within the Thatcher government there was a reluctance to devolve too much to individual consumers. It was doctors and managers, rather than patients that were empowered to make choices within the internal market, allowing for some balance between the demands of the individual and the needs of the community. Even as the marketization of health services continued apace under successive Conservative and Labour governments, the collective nature of the NHS was also reaffirmed. The $\mathcal{N} H S$ constitution of 2009, for example, set individual rights and responsibilities in the context of 'guiding principles' which reiterated the collective nature of the NHS and the care that it provided. ${ }^{110}$

All of this would suggest that the patient-consumer that was made in Thatcher's Britain was a malleable figure, bearing the marks of more than one sculptor. That by the ig9os, the government had become the lead artist is perhaps no surprise, but an alternative artwork can be discerned beneath the outline. It is this ghost image that continues to haunt attempts to make the patient-consumer today, as patients and patient groups remake this identity to suit their own ends.

\footnotetext{
108 M. Hilton, Prosperity for all: consumer activism in an era of globalisation (Ithaca, NY, and London, 2009). $\quad{ }^{109}$ D. Green, Everyone a private patient (London, I989).

110 Department of Health, The NHS constitution (London, 2009).
} 